\title{
DEBATES
}

\section{Nova direita ou vinho velho em odres novos? A trajetória conservadora no Brasil do último século}

\author{
New right or old wine in new bottles? The conservative trajectory in \\ Brazil in the last century
}

\section{Rodrigo Stumpf González \\ Marcello Baquero \\ Luis Gustavo Mello Grohmann}

\section{Resumo}

A vitória eleitoral de Jair Bolsonaro surpreendeu o mundo em 2018 não apenas por ser um candidato desconhecido de um partido pequeno, mas pelo que disse sobre mulheres, afrodescendentes, homossexuais e por seu antiquado anticomunismo da Guerra Fria. A eleição foi o resultado de uma aliança entre militares pragmáticos, neoliberais e conservadores religiosos. No entanto, não foi uma surpresa no mundo acadêmico. Este artigo tem como objetivo mostrar como, desde a terceira década do século XX, autoritários e conservadores tem participado da cena política brasileira, presentes tanto no Congresso Nacional quanto nas elites. A hipótese é que um novo governo de extrema direita não constitui uma ruptura política, mas resulta de uma longa trajetória. O contexto cultural na eleição de Bolsonaro é discutido usando dados do World Values Survey e análises do pensamento político do último século. Conclui-se que, com a tradição conservadora do Brasil baseada na religião e em valores políticos autoritários, o Bolsonaro pode ser avaliado como mais do mesmo e não como uma ruptura.

\section{Palavras-chave}

Cultura Política; Conservadorismo; Autoritarismo; Brasil; Bolsonaro.

\begin{abstract}
The electoral victory of Jair Bolsonaro surprised the world in 2018 not just because he was an unknown candidate from a small party but because of what he said about women, African descendants, homosexuals, and his outdated anticommunism from the Cold War. It was the result of an alliance between pragmatic military, neoliberals and religious conservatives. But this is not a surprise in the academic world. This article aims to show how, since the third decade in the 20th century, authoritarians and conservatives are part of the political scene in Brazil, present both in the National Congress and in the elites. The hypothesis is that a new far right government is not a political break but results from a long trajectory. The cultural background in the election of Bolsonaro is discussed using data from World Values Survey and analyses of political thought in the last century. It is concluded that, with Brazil's conservative tradition based in religion and authoritarian political values, Bolsonaro can be evaluated as more of the same and not as a rupture.
\end{abstract}

\section{Keywords}

Political Culture, Conservatism, Authoritarianism, Brazil, Bolsonaro. 


\section{Introdução ${ }^{1}$}

A vitória de Jair Bolsonaro nas eleiçóes presidenciais de 2018 no Brasil causou surpresa para a maioria dos analistas políticos (e provavelmente para o próprio candidato, que tampouco esperava este resultado).

Embora o Brasil já tenha sido governado por presidentes conservadores alguns, como os militares durante o regime instaurado em 1964, chegaram ao poder por via de golpe de estado, outros, como o Marechal Dutra e Janio Quadros, alternaram medidas conservadoras com atos mais progressistas -, esta foi a primeira eleição presidencial no país com a vitória de um candidato com um discurso abertamente de extrema direita - anticomunista, defensor da ditadura, misógino, contra quilombolas e gays (MARANHÃO FILHO, COELHO e DIAS, 2018).

$\mathrm{O}$ caso de Bolsonaro tem sido incluído como parte de uma onda neoconservadora, que alguns autores chamam também de populista (NORRIS e INGLEHART, 2019). O padrão autoritário de Bolsonaro seria semelhante ao de outros líderes políticos, como Salvini, na Itália, Victor Orban, na Hungria, e Donald Trump, nos Estados Unidos (EUA).

Esse cenário tem sido objeto de diferentes análises, em especial sobre os riscos para a democracia (FOA e MOUNK, 2017; LEVITSKY e ZIBLATT, 2018; ALBRIGHT, 2018; NORRIS e INGLEHART, 2019). O Brasil abandonou o otimismo que predominou na primeira década do século a partir do afastamento da Presidente Dilma Rousseff e da posse de seu Vice, Michel Temer, com uma agenda conservadora passando a ser implementada paralelamente a uma situação de recessão econômica. $\mathrm{O}$ passo adiante foi dado com a eleição de Bolsonaro.

A preocupaçáo da maioria dos autores mencionados com o cenário internacional e a emergência de movimentos extremistas de direita não parece estar relacionada ao aspecto ideológico. Em outros momentos ocorreram guinadas à direita, como nas eleiçốes de Reagan e Tatcher, nos anos 80, e com o fim da Uniáo Soviética, nos anos 90, que náo representaram ameaças para a estrutura institucional dominante. A diferença seriam os traços autoritários das novas lideranças e movimentos.

A questão que é proposta por este trabalho é a seguinte: o Governo de Jair Bolsonaro pode ser entendido como parte da conjuntura internacional favorável à emergência de líderes autoritários, com discurso populista e agenda conservadora, ou

\footnotetext{
${ }^{1}$ Este artigo é parte da produção do projeto de pesquisa Transiçóes para o Autoritarismo ou perda de qualidade da democracia? Uma análise comparativa da trajetória das democracias na Europa e Américas no século XXI, que tem apoio de bolsa de produtividade em Pesquisa do CNPq/Brasil.
} 
deveria o caso brasileiro ser entendido como uma continuidade de um padrão já existente, com causas predominantemente endógenas, e que, portanto, não pode ser considerado algo novo ou uma ruptura com o passado recente?

A hipótese proposta por este artigo é que a situação brasileira e a eleição de Bolsonaro podem ser explicadas por características da cultura política brasileira e fazem parte de uma tradiçấo que remonta a várias décadas.

A proposição é que o Brasil nunca desenvolveu uma democracia plenamente consolidada do ponto de vista atitudinal (LINZ e STEPAN, 1996). Nesse sentido, os eventos recentes não são sinais de desconsolidação (FOA e MOUNK, 2017), mas características históricas do modelo político brasileiro. O Brasil tem uma cultura política conservadora e autoritária com raízes muito mais antigas e profundas que os outros casos citados, congruente com o perfil do candidato eleito.

Este trabalho se desenvolve com a metodologia de process tracing (GEORGE e BENNETT, 2005; SILVA e CUNHA, 2014), como case-centric work (BEACH e PEDERSEN, 2016), discutindo os processos de path dependence que vinculam as experiências do passado ao domínio das características culturais do presente.

$\mathrm{Na}$ primeira parte do artigo será apresentada a fundamentação teórica na teoria da cultura política e os conceitos de conservadorismo e autoritarismo. Em seguida, é apresentada a trajetória política brasileira e a formação da cultura política no país conforme descrita na literatura, destacando o papel na religiáo e da Igreja Católica. Por fim, são analisados os dados do World Values Survey das ondas do período 1991 a 2018, buscando verificar quais as características dominantes da cultura política, sua estabilidade e grau de congruência com as mudanças políticas recentes. Nas conclusóes, analisa-se a relação entre esse passado e a vitória de Bolsonaro.

\section{A teoria da cultura politica}

Um dos focos de analistas que têm discutido a emergência de governantes com traços autoritários, como Levitsky e Zieblatt (2018), é a incapacidade das normas institucionais de serem uma barreira eficiente para o comportamento extremado dos líderes políticos. Suas ações são criticadas por alguns, mas apoiadas por uma ampla parcela da população e mesmo por representantes nas esferas políticas, como indicam a absolvição de Trump no processo de impeachment e a aprovaçáo do Brexit.

A insuficiência dos mecanismos institucionais e da racionalidade para explicar os eventos políticos reforçou a importância das análises feitas a partir da cultura política. 
Ainda que a importância de traços culturais na definição das instituiçóes políticas encontre precedentes tão antigos como A República, de Platão, Comentários sobre a Primeira Década de Tito Lívio, de Maquiavel, e a Democracia na América, de Tocqueville (ALMOND, 1996), os estudos de cultura política tiveram impulso com a pesquisa de Almond e Verba (1963), nos anos 60, com uma abordagem que buscava unir teoricamente com a Ciência Política contribuiçôes da Antropologia, da Psicologia Social e da Teoria dos Sistemas.

$\mathrm{Na}$ tentativa de compreender as diferenças de funcionamento de múltiplos sistemas políticos, o objetivo era superar o paradigma institucionalista e racionalista dominante na Ciência Política e tributário do iluminismo e da filosofia política contratualista, que descreve a política e os sistemas políticos como um conjunto de regras definidas por atores racionais, em geral, os membros de uma elite - substituindo por uma versão empiricamente fundamentada e metodologicamente amparada no positivismo científico (ALMOND e VERBA, 1963).

Segundo a teoria da cultura política, o funcionamento e a estabilidade das instituiçóes políticas são afetados pela congruência entre o modelo institucional e os valores e atitudes predominantes na sociedade, adquiridos pelo processo de socialização política.

Essa agenda teórica encontrou inicialmente duas barreiras: de um lado, a própria limitação do modelo conceitual proposto pelos autores, com o padrão da cultura cívica ancorado ideologicamente nos Estados Unidos da América como ideal, e, de outro, a dificuldade da obtenção de dados para fundamentar as análises, levando ao declínio de seu uso nos anos 70 .

A teoria da cultura política deve seu renascimento e sua expansão pelo mundo, em parte, à criação de surveys internacionais, como o Eurobarômetro e o World Values Survey, que permitem hoje a análise de múltiplos países e de séries históricas de evolução de valores e atitudes nas últimas décadas, com destaque para a contribuiçáo de Ronald Inglehart na construção dessas bases de dados (FERNANDEZ-PRADOS, CUENCA-PIQUERAS e GONZÁLEZ-MORENO, 2019).

A terceira onda da democracia favoreceu a coleta de dados. Regimes autoritários em geral são desconfiados de consultas diretas à população e de entrevistadores espalhados pelo país fazendo perguntas cujas respostas não podem controlar. A liberalização de regimes pelo mundo favoreceu a institucionalização do World Values Survey e a reproduçáo, em outros continentes, do modelo pioneiro europeu de monitoramento de atitudes, o Eurobarômetro. Atualmente, estáo disponíveis dados sobre mais de uma centena de países em séries que preenchem, em diversos casos, várias 
décadas. O problema deixou de ser a ausência de dados, mas o que fazer com eles (NORRIS, 2009).

Baseando-se no modelo de David Easton (1965) de sistema político, um dos inputs relevantes é o suporte ao sistema, que pode ser subdividido em diferentes níveis de abstração, conforme propóe Norris (1999), desde o apoio e a avaliação positiva do sistema como um todo, como os valores, atitudes e avaliaçáo dos resultados das instituições e dos dirigentes políticos em particular.

Algumas teorias da transição democrática incorporaram o aspecto cultural em seus modelos. Para Linz e Stepan (1996), a consolidação da democracia tinha exigências institucionais, comportamentais e atitudinais. $\mathrm{O}$ aspecto atitudinal tem relação com o suporte pela população das novas instituiçôes, o que foi considerado particularmente sensível em países com escassa tradição democrática anterior. Nesse sentido, a visão dos "barômetros" como forma de monitorar o apoio e a satisfação com o regime.

Nessa perspectiva, a estabilidade do regime democrático e os limites aceitáveis de comportamento das lideranças políticas são resultado da congruência das instituiçóes com os valores dominantes na sociedade.

As instituiçóes e o comportamento e escolhas das elites continuam sendo relevantes, mas não são suficientes para entender a trajetória política de um país, sendo necessário considerar a cultura política como uma variável interveniente fundamental.

\section{Conservadorismo e autoritarismo}

Ainda que grande parte dos estudos de cultura política esteja centrada no conceito de democracia, o outro lado da moeda com relaçáo ao desenvolvimento desse valor é a possibilidade do predomínio na população de valores e atitudes que favoreçam o autoritarismo. Este conceito, por sua vez, pode ser associado ao de conservadorismo. A seguir são discutidos tais conceitos, sua relação e possível operacionalização.

O conceito de conservadorismo, como outros na Ciência Política, é sujeito à polissemia. Uma tentativa de definição inicial foi feita por Mannheim (1986), como uma forma de pensar, indicando já a existência de diferenças no conservadorismo britânico em relação ao alemão.

Samuel Huntington afirma que o conservadorismo é uma ideologia, mas sem um conteúdo específico. $\mathrm{O}$ ponto em comum são alguns princípios identificados com Raymond Burke: o ser humano como ser religioso; a naturalidade de uma sociedade orgânica; dar ao instinto e à emoção a mesma importância da razão; a preeminência da comunidade sobre o indivíduo; a naturalidade da desigualdade humana; a preferência 
14 | Rodrigo González, Marcello Baquero e Luis Gustavo Grohmann

por formas de governo oriundas da evolução prática com relação a novas propostas construídas teoricamente. Nessa perspectiva, o movimento conservador seria em parte uma resposta ao racionalismo iluminista (HUNTINGTON, 1957).

Para Scruton (1980), o conservadorismo é um sistema de crenças que não se constitui em um conjunto de ideias específico. Ele o considera como uma doutrina que defende determinados fundamentos, como o patriotismo e a tradição, e desconfia de princípios abstratos de direitos humanos e democracia.

O conservadorismo, portanto, pode ter diferentes conteúdos, do ponto de vista político, como uma ideologia que defende a manutenção de tradiçóes e rejeita mudanças radicais, mas que pode ser associada ao pluralismo de ideias liberal sustentado por regras do jogo, historicamente ligado às origens do Partido Republicano dos EUA ou aos Tories do Reino Unido no século XX - como, por outro lado, pode ser reacionária (ROBYN, 2017; HIRSCHMAN, 1992) e incluir características autoritárias.

Ainda que não seja impossível uma versão conservadora de esquerda (o modelo soviético na era Brejnev poderia ser descrito desta forma), o termo em geral é identificado com posiçóes de direita (BOBBIO, 2001), em particular a reacionária, e neste trabalho será usado como sinônimo do conservadorismo de direita.

Pela própria indefinição e polissemia dos conceitos de conservadorismo e autoritarismo, a passagem das análises históricas e filosóficas para os estudos empíricos traz consigo a dificuldade de operacionalização. Conservadorismo e autoritarismo são conceitos que náo se confundem, ainda que possam ter características em comum, da mesma forma que nem sempre estâo associados.

Linz (2000) aponta que o autoritarismo em geral é identificado a partir das suas diferenças em relação aos conceitos de democracia e totalitarismo, cuja construção é abstrata. Nesse sentido, a abordagem em relação ao autoritarismo tem sido mais de caráter classificatório e descritivo dos fenômenos existentes.

Uma tentativa pioneira da construçáo empírica dos conceitos foi o estudo liderado por Adorno et al. (1950), com a criação de escalas como a F (de fascismo), fundamento para a análise de traços psicológicos do conservadorismo e do autoritarismo. A complexidade das escalas, com um grande número de dimensóes e algumas inconsistências, levou a diversas críticas, como a confusão entre a medida de conservadorismo e a de autoritarismo, e ao seu abandono.

Posteriormente, Wilson e Patterson (1968) propuseram outra escala de medida para o conservadorismo. Entretanto, o debate sobre se as escalas medem autoritarismo, 
conservadorismo, ou se há uma confusão entre os conceitos, seguiu existindo com as críticas de Ray $(1973,1979)$.

Altemeyer $(1981,2006)$ renovou os estudos sobre traços autoritários da personalidade com o desenvolvimento de uma escala para o autoritarismo de direita (Right Wing Authoritarianism - RWA), reduzindo as nove dimensōes propostas por Adorno a três. A personalidade dos seguidores do autoritarismo, segundo ele, tem três traços distintivos: altos níveis de submissão à autoridade estabelecida, de agressividade em nome dessa autoridade e de convencionalismo.

Considerando os conceitos de Huntington (1957) e Scruton (1980), podemos considerar que a submissão à autoridade e o convencionalismo, duas das dimensóes propostas por Altemeyer, são também componentes do conservadorismo.

Ainda que cada um desses autores use termos diferentes, como ideologia, traços de personalidade ou cultura política, as mesmas dimensóes podem ser usadas para a análise da existência de padrôes dominantes de valores e atitudes que fundamentam um comportamento conservador e autoritário.

A presença destas características, do conservadorismo e do autoritarismo, no Brasil são discutidas a seguir, com o desenvolvimento do pensamento conservador no Brasil, sua influência sobre as instituições e a cultura política.

\section{A evolução das instituições brasileiras e a ideologia conservadora}

Conforme Faoro (1973), a formação do Estado brasileiro é uma continuidade com o modelo político português do período colonial, com um domínio constante do Estado sobre a sociedade e um amplo poder de um estamento burocrático.

A primeira constituição brasileira, de 1824, reproduzia muitos princípios liberais das constituiçóes europeias surgidas na mesma época. Porém, seu texto não foi o resultado da decisão da assembleia de representantes convocada para este fim, mas de um decreto do imperador, que dissolveu a assembleia e instituiu um texto que lhe garantia poderes superiores ao parlamento (o Poder Moderador). A escravidão foi mantida como base da economia agrária, à margem do texto constitucional (HOLANDA et al., 1960a).

As contradiçóes entre o modelo institucional e a prática são explicadas, segundo Mercadante (1965), pelas características principais do pensamento político brasileiro no Império: a conciliação e o ecletismo. O liberalismo radical teve pouco espaço. Isso se verifica na própria Proclamação da Independência, ruptura sem ruptura, com o 
príncipe herdeiro da coroa portuguesa tornando-se imperador. A acomodaçáo se dá também na manutençáo parcial do liberalismo econômico, com uma economia de exportação agrária baseada na escravidão. A própria escravidão é admitida como um arcaísmo moralmente negativo, mas a abolição é combatida em prol de um gradualismo na mudança do sistema. Segundo Trindade (1985), a política brasileira combinou um discurso liberal com práticas autoritárias.

Com a Proclamação da República em 1889, foi adotada uma Constituição que propunha um Estado Federal, com grande descentralização, a tal ponto inspirada nos EUA que o Brasil adotou o nome oficial de Estados Unidos do Brasil.

Entre os intelectuais brasileiros das primeiras décadas do século XX, há pouco espaço para a defesa de uma sociedade liberal ou a democracia como modelo político, sob a influência do positivismo e de autores como Oliveira Vianna e Alberto Torres, que defendem um Estado forte (IANNI, 2004).

Passados os primeiros anos da República sob controle militar (1889-1894), no período que vai até 1930, existiram partidos e eleiçóes, mas nem uns nem outras eram as verdadeiras portas de entrada para o poder. Abundavam as fraudes e o "voto de cabresto" - o controle dos votos da população pobre pelos proprietários de terras - os "coronéis", cujo título era uma reminiscência da guarda nacional do período imperial (LEAL, 2012). Durante quase quatro décadas, os estados de Minas Gerais e Sáo Paulo dominaram a política nacional, na chamada política do Café com Leite. Para esses governantes, o importante era manter a economia baseada na exportaçáo do café (FAUSTO et al., 2007).

Esse período, conhecido como República Velha, foi rompido pela Revolução de 1930 - "revoluçáo" no nome, tendo em vista que se tratou de um levantamento militar que levou ao poder Getúlio Vargas, o candidato derrotado nas eleiçóes daquele ano.

Na análise de Simon Schwartzman (1982), a política brasileira do período se resume em repressão ou cooptação, descartada a representação nos moldes liberais.

O Brasil dos anos 30 leva à confluência no poder de diversas ideologias de natureza autoritária, com maiores ou menores graus de conservadorismo. Enquanto os grupos oriundos do catolicismo são tradicionalistas, Getúlio Vargas traz consigo a influência do positivismo de Júlio de Castilhos. $\mathrm{O}$ movimento tenentista encontra proximidades de seus objetivos de modernização do Estado com o fascismo ou com o socialismo da III Internacional (CRIPPA, 1979; IANNI, 2004).

Ainda que sem o uso do conceito, a cultura brasileira da época é caracterizada como tendo por base as relaçôes pessoais (o brasileiro cordial) (HOLANDA, 1995), 
uma suposta democracia racial - em que a miscigenação fez parte dos costumes (FREYRE, 2019) - mas ocultando uma sociedade racista, hierárquica e autoritária (MATTA, 1979).

Entre os intelectuais importantes nos anos 30, Oliveira Viana propunha que somente um Estado forte poderia gerar o desenvolvimento no Brasil. Ao mesmo tempo, aderia a teorias racistas de autores como Le Bon para considerar que o Brasil necessitava de um "branqueamento", com uma ampliação dos tipos arianos (CARVALHO, 2004). Gilberto Freyre, em Casa Grande e Senzala, por outro lado, propôe a análise contrária, de que a miscigenação seria a grande característica do brasileiro que evitaria a discriminação, sendo a base de uma "democracia racial".

Se com Oliveira Viana aparece o racismo nu e cru, que apontava náo apenas os não-brancos, mas inclusive os caucasianos do sul da Europa como inferiores, a interpretação de Gilberto Freyre contribuiu para que o racismo presente na sociedade brasileira fosse escondido sob o manto da tolerância e das manifestaçôes populares (MATTA, 1979). Embora a defesa aberta da superioridade branca tenha se tornado marginal nos dias de hoje, a negação da existência do racismo ainda é um traço dominante da sociedade brasileira.

A religião dominante desde a colonizaçáo, o catolicismo, diante do surgimento de movimentos políticos como o anarquismo e o comunismo, fez com que a Igreja se tornasse politicamente ativa, tanto em termos de movimentos sociais como de representaçáo parlamentar, seguindo uma trajetória influenciada pela Guerra Fria de forte discurso anticomunista (RODEGHERO, 2002).

A modernizaçáo econômica que o Brasil realizou a partir da segunda metade da década de 30, com um processo de industrialização por substituição de importaçôes, teve, entre os protagonistas, os militares brasileiros, que tomaram para si a tarefa da modernização, associada a um discurso nacionalista, mas com um arraigado conservadorismo de costumes e, após uma depuração de quadros depois da fracassada revolta militar de 1935, fortemente anticomunista (FAUSTO et al., 2007).

A urbanização e a expansão dos direitos dos trabalhadores e da cidadania, no entanto, difere da trajetória descrita por Marshall (1967) para o Reino Unido. Conforme Santos (1979), o que foi criado era uma cidadania regulada, outorgada pelo Estado. Segundo Carvalho (2008), no Brasil, os direitos sociais como concessão do Estado antecedem os direitos civis e políticos, que nunca alcançaram o mesmo apoio por parte da população. 
Essa perspectiva une tanto governos considerados de esquerda, como os de Getúlio Vargas (1951-1954) e João Goulart (1961-1964), como a direita, como a criação da aposentadoria dos trabalhares rurais pelo Regime Militar. A existência de um Estado paternalista, para alguns, pode ser identificada mesmo em políticas mais recentes, como o Bolsa-Família, carro-chefe dos programas sociais do Governo Lula.

Sob a influência do corporativismo de influência fascista oriundo da legislação do trabalho de 1943 (CLT), ainda hoje é mantido um sistema de unidade sindical em que só pode haver um sindicato por categoria profissional em uma determinada regiáo, autorizado pelo Estado, e que até recentemente (2017) contava com um sistema de contribuiçôes compulsórias, cobradas mesmo dos não filiados.

O período 1946-1964 foi de relativa democracia e eleiçôes competitivas, mas é difícil definir a predominância conservadora do eleitorado brasileiro com base nos resultados eleitorais, devido a certa fluidez ideológica dos partidos brasileiros.

Em 1946 surgiu um sistema de quatro grandes partidos (PCB/PTB/PSD/UDN), com a exclusão posterior do Partido Comunista Brasileiro (PCB), com registro cassado em 1947. A UDN representava uma direita urbana, com discurso conservador mais radicalizado em alguns momentos; o PSD, a direita agrária, mas moderada; e o PTB reunia os setores dos trabalhadores urbanos e a esquerda, com a absorção do voto dos comunistas quando estes foram colocados na ilegalidade (SOUZA, 1976). Em geral, o PSD e o PTB aliaram-se nas eleiçóes presidenciais, mas alguns membros do PSD apoiaram o golpe de 1964, contra Goulart, do PTB. Outros partidos com posição mais extremada e de posição ideológica mais explícita, em geral, tiveram representação eleitoral menor.

A eleição do Marechal Eurico Gaspar Dutra, do PSD, em 1945, não pode ser atribuída à formação de uma maioria conservadora - ainda que, em termos de suas açóes, tenha um governo com marcada identidade anticomunista, com a adesão ao discurso norte-americano da Guerra Fria e medidas de caráter moralista, como a proibição do funcionamento dos cassinos - tendo em vista ele ter contado com o apoio do PTB e a aprovação tácita de Getúlio Vargas.

Nesse período, militares, como Golbery do Couto e Silva, contribuíram, na Escola Superior de Guerra, para a construção de um pensamento conservador marcado pela Guerra Fria e a Doutrina da Segurança Nacional (COUTO E SILVA, 1967; FERNANDES, 2009).

Mesmo a eleição de Jânio Quadros, da UDN, em 1960, pode ser colocada em dúvida como uma votaçáo que indique uma maioria estável conservadora, pois, sendo separadas, na época, a votação para presidente e vice-presidente, o candidato da UDN 
a vice-presidente, Milton Campos, foi derrotado por João Goulart, do PTB. Na Câmara dos Deputados, os partidos que podem ser considerados de direita mantiveram a maioria das cadeiras.

Após o Golpe de 1964 e a reforma do sistema partidário, com a adoção de um bipartidarismo, em que a ARENA representava o regime e uma oposiçáo consentida se reunia no MDB, o cálculo tampouco é simples. Embora a ARENA tenha mantido uma maioria no Congresso, esta náo refletia necessariamente uma maioria do eleitorado. Por outro lado, alguns membros do MDB pertenceram a partidos conservadores no sistema anterior, vinculando-se à oposição por discordar do regime militar.

$\mathrm{O}$ próprio regime militar teve suas dubiedades. Ao mesmo tempo em que reprimiu sindicatos e movimentos de esquerda, apoiou medidas que entraram em choque com o conservadorismo de costumes, como a aprovação do divórcio.

No sistema bipartidário do regime militar, estar na oposição significava não aceitar o modelo institucional do regime, mas não necessariamente uma visão progressista em termos de costumes ou valores sociais, o que foi aproveitado pelo próprio regime com a reforma partidária de 1979, que manteve o partido sucessor da Arena - o PDS, como maior partido, dividindo a oposição em diversos partidos.

O triunfo avassalador do PMDB nas eleiçôes de 1986, com a eleição da maioria dos governadores de Estado e tornando-se o maior partido na Câmara e no Senado, náo significou necessariamente uma guinada à esquerda do país, mas, sim, a ampliação desse partido, que incluiu em seus quadros segmentos de diversas origens políticas, como o próprio Presidente José Sarney, que foi Senador pela Arena.

A grande fragmentação partidária do Congresso brasileiro, vista como compatível com a democracia pelos teóricos do Presidencialismo de Coalizão, levou, depois da redemocratização, à formação de coalizóes de mais de uma dezena de partidos nos governos nacionais de 1989 até hoje, o que permitiu ocultar a existência de um perfil ideológico dos governos, em geral descritos a partir das características pessoais do presidente ou de algumas de suas iniciativas mais chamativas do que pelas características ideológicas ou agenda de sua base de apoio no Congresso Nacional.

Do ponto de vista institucional, depois da independência, o país viveu dois períodos de relativa normalidade democrática: 1946-1964 e 1985 até hoje. No entanto, mesmo nesses dois períodos, ocorreram tentativas de golpe ou rupturas institucionais mais brandas, como a aprovação da emenda parlamentarista em 1961 como requisito para permitir a posse de João Goulart, ou os afastamentos dos Presidentes Fernando Collor de Melo e Dilma Rousseff, sem que tenha havido condenaçáo pessoal posterior 
pelos crimes imputados - Collor absolvido por falta de provas pela Suprema Corte, Dilma inocentada pelo próprio Senado que aprovou seu afastamento.

Levando em conta essa trajetória política, discute-se a seguir quais as características dominantes da cultura política que poderiam contribuir para explicar esses eventos.

\section{Cultura politica no Brasil}

O Brasil passou a realizar tardiamente estudos de cultura política. O período ditatorial, de 1964 a 1985, limitou os estudos acadêmicos a amostras locais e a restrição aos processos eleitorais (foram eliminadas as eleiçóes diretas para presidente, governadores de estados e prefeitos das capitais dos estados). Estudos dos anos 70 e 80, em geral, se concentraram na análise do comportamento eleitoral (LAMOUNIER e CARDOSO, 1975; REIS et al., 1978; FLEISCHER et al., 1988). As primeiras pesquisas com amostras nacionais somente foram realizadas em 1989 (MOISÉS, 1995).

Para o período anterior a 1989, as análises são fundamentadas em abordagens sob a influência da sociologia weberiana ou da antropologia, nas obras fundadoras das Ciências Sociais brasileira, de autores como Holanda, Freyre, Leal ou Faoro, já referidos (IANNI, 2004).

Os autores que desenvolveram estudos de cultura política nas últimas décadas, como José Alvaro Moisés e Marcello Baquero, em geral desenvolveram uma visão mais pessimista do regime político que os analistas institucionalistas.

Para Moisés (1995), as imagens que traduzem cultura política brasileira são bem conhecidas: clientelismo, populismo, atitude deferencial diante das autoridades, manipulação, apatia política e, por último, antipartidismo e anti-institucionalismo. Segundo o autor, acreditando-se nas interpretaçóes mais conhecidas, os padrôes político-culturais dominantes desautorizam mesmo as expectativas mais pessimistas quanto à possibilidade de constituir-se uma esfera pública enraizada em uma definição ampla de direitos políticos no Brasil. Segundo Moisés (1995, p. 231): "Um dos principais problemas da democracia brasileira nos anos 90 , consiste, portanto, em que os elementos antidemocráticos herdados do passado continuam ocupando o terreno onde as inovaçóes democráticas devem se enraizar”.

Sua conclusão, em 1995, era de um otimismo moderado, percebendo a sobrevivência de valores autoritários em parte da sociedade, mas acreditando que estava em processo a constituição de uma nova cultura política baseada no consenso de apoio à democracia, com uma diminuição contínua do apoio a soluçóes autoritárias. Moisés 
alertava que a elite política deveria aproveitar a "lua-de-mel" da populaçáo com o novo regime e realizar reformas (MOISÉS, 1995).

A existência de atitudes ambivalentes com relação à democracia também é apontada por Linz e Stepan (1996) como um risco para a sua consolidação, ao lado dos problemas de um sistema partidário fragmentado e do presidencialismo.

Uma vez que a tendência de democratizaçáo dependeria da avaliação do comportamento das elites, e a reserva de boa vontade poderia se esgotar rapidamente em um momento de crise, passada mais de uma década, esse otimismo não se confirmou. E, se considerarmos a década seguinte, o pior dos cenários veio a se realizar.

A análise de Moisés (2008) identifica a existência de uma cultura política ambivalente, em que a aceitaçáo da democracia entre os brasileiros é vista como compatível com comportamentos autoritários, como a intervenção dos militares. Assim, quando parte dos brasileiros defende a democracia, está falando de algo bastante distinto do modelo liberal ou do que Linz e Stepan (1996) chamaram de "the only game in town".

Nesse mesmo sentido, estão as análises de Marcello Baquero (2001, 2012), para quem o Brasil desenvolveu uma cultura política híbrida, em que a evolução das instituições formais não foi acompanhada pela formação de uma base de confiança. Segundo o autor, a ausência de confiança institucional e de confiança interpessoal, com baixos níveis de capital social, explica a manutenção de práticas como o clientelismo e a baixa participação, criando uma democracia frágil e incompleta.

Esse autor denominou o fenômeno de "democracia inercial", em que a capacidade de transformação das instituiçôes políticas, com a realização de eleiçôes contínuas, não foi capaz de mudar as características autoritárias presentes na cultura política anterior, que sobreviveram à mudança institucional (BAQUERO, 2018; BAQUERO e GONZÁLEZ, 2016).

Algumas dessas características estão associadas à presença de um alto grau de convencionalismo, como o respeito reverencial pela autoridade (o "você sabe com quem está falando” referido por Matta (1979)). Porém, ao lado do convencionalismo, há também elementos de agressividade no suporte de determinadas políticas. $\mathrm{O}$ moralismo esteve presente de forma constante em grande parte das eleiçóes brasileiras, indicando que é um fator de mobilizaçáo do eleitorado mais importante do que a divisão ideológica tradicional entre direita e esquerda ou entre capital e trabalho.

Jânio Quadros, em 1960, fez da vassoura o símbolo de sua campanha presidencial, centrada na denúncia da corrupção. A campanha de Collor de Mello, em 
1989, foi construída em torno do apelo ao combate à corrupção e ao combate aos privilégios de um conjunto de agentes públicos com salários e benefícios escandalosos. O apelo ao moralismo também se fez presente na disputa do segundo turno entre Lula e Collor de Melo, nas eleiçôes de 1989, quando, ao final da campanha, Collor faz uso de um depoimento de uma ex-mulher de Lula, alegando que ele teria proposto que ela fizesse um aborto do que viria a ser a primeira filha do casal, pecado imperdoável em um país católico.

Quase tão imperdoável foi a hesitação de Fernando Henrique Cardoso quando candidato a prefeito de Sáo Paulo em 1986, em uma entrevista poucos dias antes da eleição, em uma disputa acirrada com Jânio Quadros - quando perguntado se acreditava em Deus, em um episódio que alguns analistas consideram ter sido fundamental para a eleição de Jânio.

As campanhas eleitorais de 1994 a 2006, em que PT e PSDB foram os partidos centrais da disputa, centraram o debate em questôes econômicas, como a estabilidade da moeda, o controle da inflação, a geração de empregos e o papel do Estado na economia.

Em 2010, o debate ideológico retornou ao terreno pessoal, com uma exploração do passado político da candidata Dilma Rousseff. Uma foto de seu prontuário policial dos anos 70, quando foi presa como afiliada a um grupo da guerrilha urbana que lutava contra a ditadura, foi utilizada para denunciar seu passado esquerdista. A tentativa resultou em efeito inverso. A mesma foto, com um efeito visual que reproduzia o utilizado na primeira campanha de Barack Obama, passou a ser um dos símbolos usados nas redes sociais pela campanha de Dilma, de um lado para demonstrar que a candidata não tinha nada a esconder, e de outro para atrair um eleitorado jovem, ao demonstrar que a tecnocrata pouco afeita à demonstração de emoçôes teve uma juventude de luta e sofrimento na busca de seus ideais.

Esse episódio marcou o retorno do anticomunismo, que havia sido um dos elementos centrais na disputa política no Brasil entre os anos 50 e 70, como tentativa de deslegitimar um candidato, o que esteve presente também nas campanhas de 2014 e 2018, com discursos que se assemelham muito aos da Guerra Fria, sem dar-se conta de estarem fora de época.

Para entender o processo de formaçáo destas características da cultura política brasileira, a seguir é discutida a influência da religião na sociedade brasileira. 


\section{A influência da religião}

A religiosidade é uma das características que se destacam na população brasileira, como será apresentado na análise dos dados do WVS mais adiante. Portanto, para entender a cultura política brasileira, é fundamental observar a trajetória das Igrejas e do pensamento religioso ao longo dos últimos séculos.

No período colonial, a Contrarreforma teve influência no processo de ocupação do território, como na ação dos jesuítas na evangelização das populaçôes indígenas e nas guerras pelo controle do território contra os holandeses (HOLANDA, 1960a).

Proclamada a independência, o catolicismo manteve-se como religiáo oficial do Estado e manteve praticamente o monopólio da fé. Os povos de origem africana, escravizados e proibidos de praticar suas religiôes, encontraram no sincretismo, com a equivalência de suas divindades com os santos católicos, uma saída. Apenas com a imigração alemã houve tolerância para o surgimento de uma comunidade cristã protestante.

A autonomia e a ligação da religião com o Estado eram garantidas pela nomeaçáo dos bispos, o que veio a gerar conflito com o Papa, contribuindo, entre outros fatores, para a desestabilizaçáo da monarquia, no que foi chamado de "a questão religiosa”. A Proclamação da República separou Estado e Igreja sem diminuir o poder desta (HOLANDA, 1960b).

$\mathrm{O}$ catolicismo brasileiro da primeira metade do século XX foi predominantemente conservador e, em alguns casos, abertamente reacionário, como $\mathrm{o}$ grupo que se reunia em torno de Jackson de Figueiredo, com influência dos reacionários franceses, como De Meistre. $\mathrm{O}$ anticomunismo com um discurso maniqueísta, que será mais comum nas décadas de 50 e 60, com a influência da Guerra Fria, já se encontrava presente nos escritos de Figueiredo nos anos 20 (CRIPPA, 1979).

A tentativa de maior penetraçáo no proletariado, sob a influência das encíclicas papais (Rerum Novarum e Quadragesimo Anno), se deu tardiamente e com pouco sucesso, com o espaço já ocupado pelos comunistas e pelo sindicalismo de natureza corporativa, sob o controle estatal e influência do fascismo italiano (FAUSTO et al., 2007).

As mudanças na Igreja Católica nas décadas que seguem a II Guerra Mundial, a partir de papados mais progressistas, de João XXIII e Paulo VI, também se refletem no Brasil. A formação da Confederação Nacional dos Bispos do Brasil - CNBB, em 1952, sob inspiração de Dom Helder Câmara, contribuiu para a mudança da 
orientação da Igreja no país e serviu de modelo a outras conferências episcopais no resto do mundo (GONZÁLEZ, 1994).

Nesse período, surgiram movimentos sociais católicos de esquerda, em organizações como a Juventude Universitária Católica, a Juventude Operária Católica e a Ação Popular. Posteriormente, em um processo de radicalização provocado pela ditadura militar, muitos de seus membros passaram para a clandestinidade e a guerrilha urbana (POERNER, 1968). No entanto, a Igreja Católica também manteve uma forte ala reacionária, com peso particular da TFP - Associação de Defesa da Tradição, Família e Propriedade, com um discurso radical e maniqueísta que rejeitava qualquer reforma, tanto em termos de sistema econômico como em termos de costumes, com um conservadorismo até mesmo nas formas de vestir ou de corte de cabelo (CRIPPA, 1979).

O protagonismo de setores da Igreja foi importante nas mobilizaçóes que antecederam o golpe militar, como as Marchas da Família com Deus pela Liberdade, dos primeiros meses de 1964, que ajudaram a dar a justificativa de cruzada anticomunista na derrubada de um governo cuja característica, no máximo, era de um reformismo nacionalista.

Embora tenha apoiado o golpe militar, a Igreja Católica teve um protagonismo importante na denúncia de violaçóes de direitos humanos durante a ditadura, com a atuação de membros da hierarquia, como o Bispo Dom Helder Câmara e o Cardeal Dom Paulo Evaristo Arns, de organismos como as Comissóes de Justiça e Paz das dioceses, mas também na divulgação da Teologia da Libertação e organização das Comunidades Eclesiais de Base (CEB), que serviram como espaços de organização popular em um período em que o regime limitava a ação de partidos e sindicatos (GONZÁLEZ, 1994). Essas organizaçôes foram uma das bases de fundação do Partido dos Trabalhadores, em 1979, em uma rara associação entre sindicalistas, movimentos cristãos e organizaçóes trotskistas clandestinas (MENEGUELLO, 1987).

Porém, com o papado de Joáo Paulo II, o pêndulo retornou para o setor conservador, e o discurso da Igreja retoma temas tradicionais, como a evangelização. Cresceu a importância de organizaçóes e movimentos conservadores, como a Opus Dei, em setores intelectuais. As resistências foram vencidas, como pela condenação do Frei Leonardo Boff - um dos construtores da Teologia da Libertação - ao silêncio, por supostamente contradizer a doutrina católica, que foi decidida pelo entáo Cardeal Ratzinger (GONZÁLEZ, 1994).

O catolicismo mantém um papel importante no Brasil desde sua formação, ainda que sua prevalência venha diminuindo nas últimas décadas. Até a década de 80 , 
o país era identificado majoritariamente como católico, podendo inclusive ser considerado o maior país católico do mundo. A Igreja Católica dividia o espaço com identidades religiosas em geral identificadas com grupos de imigração específica protestantismo luterano entre os imigrantes alemães, Igreja cristão-ortodoxa para ucranianos e outros imigrantes que vieram do leste europeu (excetuando os poloneses, em geral católicos), budismo e xintoísmo entre a comunidade nipo-brasileira, e o sincretismo das religiōes afro-brasileiras entre os descendentes de africanos A partir dos anos 70 , começou a crescer a importância das igrejas evangélicas, conforme indicam os dados dos censos demográficos (Tabela 1), com um peso particular das igrejas pentecostais, muitas fundadas no próprio Brasil (CAMPOS, 2008).

Tabela 1 - Religiôes na População do Brasil

\begin{tabular}{l|c|c|c|c}
\hline Ano & Católicos & Evangélicos & Outras Rel. & Sem religião \\
\hline $\mathbf{1 9 4 0}$ & 95,2 & 2,6 & 1,9 & 0,2 \\
\hline $\mathbf{1 9 5 0}$ & 93,7 & 3,4 & 2,4 & 0,3 \\
\hline $\mathbf{1 9 6 0}$ & 93,7 & 4,3 & 2,4 & -- \\
\hline $\mathbf{1 9 7 0}$ & 91,8 & 5,2 & 2,3 & 0,8 \\
\hline $\mathbf{1 9 8 0}$ & 89,0 & 6,6 & 2,5 & 1,6 \\
\hline $\mathbf{1 9 9 1}$ & 83,3 & 9,0 & 2,9 & 4,7 \\
\hline $\mathbf{2 0 0 0}$ & 73,9 & 15,6 & 3,5 & 7,4 \\
\hline $\mathbf{2 0 1 0}$ & 64,8 & 22,1 & 5,1 & 8,0 \\
\hline
\end{tabular}

Fonte: IBGE. Censos Demográficos 1940-2010.

Os dados indicam que os cristãos são a maioria da população, com católicos ainda predominantes, mesmo que nas últimas décadas tenha se ampliado o percentual dos que se identificam como sem religiâo.

O processo mais importante de mudança se deu pelo aumento do número de evangélicos, em particular com o crescimento das igrejas evangélicas pentecostais. Com a conversão de católicos em evangélicos, e mantida a tendência, há uma projeção de que, na atualidade, os evangélicos sejam pelo menos 30\% da população (WORMALD, 2014).

Em diversos aspectos, as posiçóes dessas igrejas são mais conservadoras do que a dos católicos. E enquanto a Igreja Católica deixou, a partir dos anos 60, de participar diretamente da política partidária, várias das igrejas evangélicas estimularam a eleição de pastores e fiéis, criando uma bancada no Congresso Nacional para defender seus interesses (PRANDI e SANTOS, 2017). No entanto, há uma diferença grande entre as denominaçóes protestantes. As igrejas protestantes tradicionais, como luteranos, 
metodistas e anglicanos, estão mais distantes da política partidária, enquanto as denominaçóes pentecostais e neopentecostais, algumas de origem estadunidense e outras de criação local, como a Igreja Universal do Reino de Deus, fazem uma promoção aberta de candidatos afiliados a suas igrejas (BAPTISTA, 2007; MACHADO e BURITY, 2014).

O catolicismo, em termos demográficos, continua sendo a religião dominante no Brasil, o que o torna o maior país católico do mundo em número absoluto de fiéis. Esse domínio, aliado à origem de religião oficial até a Proclamação da República, contribui para a rejeição ao laicismo e à separação absoluta entre Igreja e Estado, nos moldes da França.

Assim, há uma contradição entre o texto constitucional, segundo o qual o Estado é laico, e o mundo real. Sob a inspiração do papel moeda dos EUA, as notas do Real tem a inscrição "Deus seja louvado". Grande parte das repartiçôes federais tem crucifixos, o que pode ser visto, por exemplo, no plenário do Supremo Tribunal Federal. A maioria dos feriados são não apenas cristãos, como Natal e Sexta-Feira Santa, mas especificamente católicos, como os referentes à Padroeira do Brasil, Nossa Senhora de Aparecida, e aos santos padroeiros de cada estado e município da federaçáo (a legislação limita que estes proclamem feriados em datas cívicas, mas permite datas religiosas).

Diante da pressáo social que torna quase inaceitável declarar-se ateu ou agnóstico, uma das definiçóes comuns é a de católico não praticante - vinculado formalmente à religião por tradição familiar e realização de cerimônias como o batismo na infância, mas sem participação regular em ritos religiosos.

Embora o predomínio do catolicismo não deva ser ameaçado, ao menos na próxima década, há indicativos de que seu quase monopólio não só desapareceu como tem dado lugar a um pluralismo em que outras denominaçôes cristâs, em especial do protestantismo neopentecostal, ocupam um espaço cada vez maior, relacionado à conquista de novos fiéis pela conversáo de anteriormente afiliados ao catolicismo.

Por isso não é uma surpresa as semelhanças entre a pauta apresentada pelo movimento neoconservador de inspiração cristã por trás da eleição de Ronald Reagan, descrita por Jorstad (1987), e a pauta da campanha eleitoral de Bolsonaro, como uma convergência que encontra uma origem na influência religiosa mais do que nos aspectos ideológicos puramente políticos.

Assim, a cultura dominante hoje deve muito catolicismo, mas tem uma crescente influência do protestantismo, com maior capacidade de mobilização política (PRANDI e SANTOS, 2017) e posiçôes mais conservadoras que as outras 
denominações religiosas (WORMALD, 2014). A religião, assim, seria um fator de manutençáo de valores tradicionais, contrabalançando o efeito de mudanças na estrutura econômica da sociedade (INGLEAHRT e WELZEL, 2005).

A seguir analisamos os dados do World Values Survey do período 1991-2018 sobre como essa influência se reflete nos valores e atitudes dominantes, tanto com relação a costumes quanto a instituições políticas, e se é possível verificar uma tendência de mudança para um perfil mais conservador e autoritário no período recente ou se este é um traço que já pode ser identificado no período da redemocratização, como uma continuidade dos padróes que foram descritos pelos autores que debateram as instituiçôes e a cultura brasileira na primeira metade do século XX.

\section{Evolução da cultura politica brasileira nas últimas décadas}

Em primeiro lugar, são analisados dados referentes à religiosidade e a valores que definem um determinado padrão moral sobre o que é aceitável na sociedade, como família, papel da mulher na sociedade, direito à vida e autonomia para decidir e uso da violência.

Em seguida, são discutidas as atitudes e comportamentos referentes à interação coletiva e participação política, envolvendo associativismo, definição de democracia e de modelo de regime político.

Tabela 2 - Evolução da Crença Religiosa no Brasil - 1991-2018

\begin{tabular}{l|c|c|c|c|c}
\hline Crê em & 1991 & 1997 & $\mathbf{2 0 0 6}$ & $\mathbf{2 0 1 4}$ & $\mathbf{2 0 1 8}$ \\
\hline Deus & 98,5 & 99,1 & --- & 98,8 & 97,6 \\
\hline Inferno & 38,6 & 49,3 & --- & 68,2 & 68,7 \\
\hline Paraiso & 75,6 & 82,4 & --- & -- & 80,7 \\
\hline É pessoa religiosa & 87,6 & 85,4 & 88,4 & 82,5 & 75,3 \\
\hline $\mathrm{N}$ & 1782 & 1143 & 1500 & 1486 & 1762 \\
\hline
\end{tabular}

Fonte: WVS 1991-2018. Resposta Sim.

Os dados da Tabela 2 demonstram a importância da religiosidade na cultura brasileira. Ainda que com uma pequena queda, três quartos da população adulta se consideram pessoas religiosas. Em relação à natureza das crenças, um percentual médio de $98 \%$ da população afirma acreditar em Deus, o que é superior inclusive ao percentual da populaçáo brasileira que afirma ter uma religiáo, o que indica que a crença em uma divindade pode se manter mesmo com a erosão da afiliação religiosa, como já propunham Inglehart e Welzel (2005). 
Mantendo-se relativamente estável o percentual, 80,7\% em 2018 afirmava crer no paraíso. Mais surpreendente é o amplo crescimento dos que afirmam crer no inferno, passando de 38,6\% em 1991 para 68,7\% em 2018.

Os dados indicam que o Brasil, apesar de outras características da modernização, como urbanização da população, decréscimo da mão de obra no setor primário e amplo acesso a novas tecnologias, como internet e telefones celulares, não passou por um processo de laicização. A população mantém um perfil tradicional de crenças religiosas, dominadas pelas igrejas cristâs.

Tabela 3 - Afirmaçóes sobre comportamento e família ${ }^{2}$

\begin{tabular}{l|c|c|c|c|c}
\hline & 1991 & 1997 & 2006 & 2014 & 2018 \\
\hline $\begin{array}{l}\text { Um dos meus principais objetivos na vida é } \\
\text { fazer meus pais se orgulharem de mim. }\end{array}$ & --- & 87,7 & 88,2 & 90,6 & 92,1 \\
\hline $\begin{array}{l}\text { Quando a máe tem um trabalho remunerado, } \\
\text { as crianças sofrem. }\end{array}$ & 75,2 & --- & --- & 61,7 & 56,3 \\
\hline $\begin{array}{l}\text { Ser dona de casa traz tanta realizaçáo quanto } \\
\text { trabalhar fora e ganhar salário. }\end{array}$ & 60,6 & 60,8 & 50,9 & 46,5 & 49,9 \\
\hline $\begin{array}{l}\text { Se a mulher ganha mais dinheiro que o seu } \\
\text { marido, é quase certo que isso causará } \\
\text { problemas. }\end{array}$ & --- & --- & --- & 34,6 & 36,8 \\
\hline $\begin{array}{l}\text { De modo geral, os homens fazem negócios } \\
\text { melhor do que as mulheres. }\end{array}$ & --- & --- & 29,0 & 27,7 & 21,9 \\
\hline $\begin{array}{l}\text { Quando há poucos empregos, os homens } \\
\text { devem ter mais direito a um emprego do que } \\
\text { as mulheres. }\end{array}$ & 38,7 & 35,6 & 21,9 & 16,2 & 19,1 \\
\hline $\begin{array}{l}\text { De modo geral, os homens sáo melhores } \\
\text { líderes políticos do que as mulheres. }\end{array}$ & --- & 47,2 & 30,9 & 28,2 & 18,6 \\
\hline $\begin{array}{l}\text { Fazer faculdade é mais importante para os } \\
\text { homens do que para as mulheres. }\end{array}$ & --- & 24,1 & 11,4 & 9,4 & 9,8 \\
\hline $\mathrm{N}$ & 1782 & 1143 & 1500 & 1486 & 1762 \\
\hline
\end{tabular}

Fonte: WVS 1991-2018. Respostas concorda totalmente ou concorda.

Os dados da Tabela 3 indicam uma relativa evolução na misoginia, com uma redução efetiva na avaliação negativa da capacidade feminina de ocupar funçóes de mando, diminuindo de 47,2 para $18,6 \%$ os que consideravam que homens são melhores líderes e dos que consideram que homens são melhores executivos de

\footnotetext{
${ }^{2}$ Todos as tabelas reproduzem os percentuais apenas dos que responderam a questão, excluindo as não respostas.
} 
empresas. Porém, ainda que tenham diminuído, permanecem em percentuais altos os que consideram que o trabalho da mulher prejudica os filhos pequenos, que a vida de dona de casa é táo importante como o trabalho, e um percentual de 36,8\% que considera um problema que a mulher ganhe mais que o homem.

Embora tenha havido uma evolução, em geral não há diferenças profundas entre a posição de homens e mulheres sobre as questôes, mesmo tomando 2018 como referência. Com relação a considerar recompensador ser dona de casa, a diferença era de $51,8 \%$ para homens para $48,5 \%$ para as mulheres, e de $45,2 \%(\mathrm{H})$ e $56,9 \%(\mathrm{M})$ com relação a ser um problema que as mulheres tenham maior remuneração que os homens, contraintuitivamente sendo as mulheres que identificam este como um maior problema. Para 30,7\% dos homens, eles são melhores negociantes, contra $14,7 \%$ das mulheres que concordam com a afirmação.

Percebe-se uma maior aceitaçáo da capacidade das mulheres no mercado de trabalho, com o reconhecimento de sua liderança. Porém, permanece uma maioria em ambos os sexos que avalia positivamente um modelo tradicional de família, em que a mulher é dona de casa e tem a responsabilidade de cuidar dos filhos, cuja principal tarefa é fazer orgulhosos os pais.

Esse perfil pode ser verificado na posição sobre temas que dependem da moralidade, como se verificada na Tabela 4.

Tabela 4 - Considera que é justificável?

\begin{tabular}{|c|c|c|c|c|c|c|}
\hline & & 1991 & 1997 & 2006 & 2014 & 2018 \\
\hline \multirow[t]{3}{*}{ Divorcio } & Média & 4,9 & 4,9 & 5,6 & 6,2 & 6,2 \\
\hline & $\mathrm{N}$ & 1764 & 1137 & 1472 & 1456 & 1679 \\
\hline & $s$ & 3,4 & 3,4 & 3,2 & 3,4 & 3,4 \\
\hline \multirow[t]{3}{*}{ Homossexualidade } & Média & 2,4 & 3,2 & 4,3 & 4,6 & 5,0 \\
\hline & $\mathbf{N}$ & 1764 & 1127 & 1445 & 1403 & 1506 \\
\hline & $s$ & 2,5 & 3,0 & 3,0 & 3,4 & 3,5 \\
\hline \multirow[t]{3}{*}{ Prostituiçáo } & Média & 2,0 & 2,3 & 3,1 & 3,0 & 3,2 \\
\hline & $\mathrm{N}$ & 1776 & 1133 & 1473 & 1440 & 1606 \\
\hline & $s$ & 2,0 & 2,4 & 2,6 & 2,8 & 2,9 \\
\hline \multirow[t]{3}{*}{ Aborto } & Média & 2,5 & 2,0 & 2,4 & 2,3 & 2,5 \\
\hline & $\mathrm{N}$ & 1777 & 1136 & 1480 & 1468 & 1677 \\
\hline & $s$ & 2,3 & 2,2 & 2,4 & 2,4 & 2,6 \\
\hline \multirow[t]{2}{*}{ Eutanásia } & Média & 2,7 & 3,0 & 3,4 & 2,5 & 3,2 \\
\hline & $\mathbf{N}$ & 1750 & 1129 & 1467 & 1446 & 1615 \\
\hline
\end{tabular}




\begin{tabular}{l|l|c|c|c|c|c}
\hline & $\mathbf{s}$ & 2,8 & 3,0 & 3,1 & 2,7 & 3,2 \\
\hline \multirow{3}{*}{ Suicídio } & Média & 1,4 & 1,5 & 1,8 & 1,6 & 2,1 \\
\cline { 2 - 7 } & $\mathbf{N}$ & 1778 & 1135 & 1484 & 1473 & 1679 \\
\cline { 2 - 7 } & $\mathbf{s}$ & 1,4 & 1,5 & 1,8 & 1,8 & 2,3 \\
\hline
\end{tabular}

Fonte WVS 1997-2018. 1=nunca 10= sempre. Os dados são médias e desvio padrão.

Nessas variáveis, quanto mais perto de 1 a média, menos aceitável é o comportamento. Pode-se verificar que o aborto, o suicídio, a eutanásia e a prostituição são considerados inaceitáveis. Embora ainda vistos por muitos de forma negativa, a homossexualidade e o divórcio na última década passaram a ser mais tolerados, mas com maior polarização das divisóes.

Para alguns temas, a posição mais conservadora permanece inalterada, enquanto para outros se nota uma pequena evolução a uma maior tolerância por visóes de mundo diferentes. $\mathrm{O}$ convencionalismo dominante indica uma sociedade de padrão conservador em termos de costumes, com uma clara influência do pensamento cristáo.

A concepção moral sobre a violência, na Tabela 5 mostra que é totalmente inaceitável roubar ou usar violência contra a esposa ou outras pessoas. Porém, a percepção é muito mais dividida com relaçáo à aplicação da pena de morte e ao castigo físico aplicado aos filhos, que, embora não sejam aceitos pela maioria, são defendidos por um número considerável de pessoas, como indica o alto desvio padrão, sendo indicativo de uma posiçáo agressiva no uso da autoridade, que pode ser associada ao apoio a comportamentos autoritários.

Tabela 5 - Considera que é justificável? Atos violentos

\begin{tabular}{l|l|c|c|c}
\hline & & $\mathbf{2 0 0 6}$ & $\mathbf{2 0 1 4}$ & $\mathbf{2 0 1 8}$ \\
\hline Roubar & Média & --- & 1,42 & 1,52 \\
\hline & $\mathbf{N}$ & --- & 1481 & 1731 \\
\hline & $\mathrm{S}$ & --- & 1,417 & 1,611 \\
\hline Violência contra outras pessoas & Média & --- & 1,55 & 1,74 \\
\hline & $\mathrm{N}$ & --- & 1481 & 1739 \\
\hline & $\mathrm{S}$ & --- & 1,565 & 1,730 \\
\hline Marido bater na sua esposa & Média & 1,56 & 1,38 & 1,37 \\
\hline & $\mathrm{N}$ & 1491 & 1481 & 1736 \\
\hline & $\mathrm{S}$ & 1,646 & 1,357 & 1,343 \\
\hline Pais baterem nos filhos & Média & --- & 3,70 & 4,38 \\
\hline & $\mathrm{N}$ & --- & 1477 & 1729 \\
\hline & $\mathrm{S}$ & --- & 2,908 & 3,080 \\
\hline
\end{tabular}




\begin{tabular}{l|l|l|l|c}
\hline Pena de morte & Média & --- & --- & 4,13 \\
\hline & N & --- & --- & 1677 \\
\hline & S & -- & --- & 3,501 \\
\hline
\end{tabular}

Fonte WVS 1997-2018. 1=nunca 10= sempre. Média e desvio padrão.

\section{Instituições e politica}

Dada a importância da religiáo na vida pessoal, não é uma surpresa que a instituição que tem o maior número de afiliados sejam as igrejas, mantendo estabilidade, enquanto outras organizaçóes têm tido seu número de associados diminuído (Tabela 6).

Tabela 6 - Participação em Organizaçóes ou associações 1997-2018

\begin{tabular}{c|c|c|c|c}
\hline & $\mathbf{1 9 9 7}$ & $\mathbf{2 0 0 6}$ & $\mathbf{2 0 1 4}$ & $\mathbf{2 0 1 8}$ \\
\hline Igreja & 38,4 & 23,4 & 27,3 & 32,6 \\
\hline Esportiva ou recreativa & 74,2 & 81,2 & 88,9 & 85,9 \\
\hline Sindicato & 82,2 & 81,1 & 86,7 & 88,2 \\
\hline De caridade / humanitária & 69,0 & 80,0 & 85,7 & 90,0 \\
\hline Educacional ou artística & 81,9 & 85,4 & 90,7 & 91,3 \\
\hline Partido Político & 85,7 & 89,8 & 94,4 & 96,1 \\
\hline $\mathbf{N}$ & 1143 & 1500 & 1486 & 1762 \\
\hline
\end{tabular}

Fonte WVS 1997-2018. Respostas não pertence \%.

Os dados indicam o pequeno grau de participação da população brasileira em instituições de natureza associativa, com um decréscimo constante nas últimas duas décadas na participação não apenas em organizaçóes de natureza política, como partidos e sindicatos, mas também em instituiçóes de natureza cultural, de caridade ou esportiva. Mesmo o esporte, considerado um elemento de mobilização popular, não consegue atrair mais do que cerca de $15 \%$ da populaçáo. E apenas 1,6\% afirma ser membro ativo de partidos.

Assim, a instituiçấo com maior capacidade de mobilização são as igrejas, com cerca de 70\% da população indicando alguma forma de participação. Em 2018, 44,9\% declarava participaçáo ativa e $25,5 \%$ ser membro inativo, algo comum entre os católicos, que mantêm a tradição de determinados ritos, como o batismo e o casamento, mas não frequentam cotidianamente os templos, identificando-se como "católicos não praticantes".

A valorização da esfera privada e a religiosidade também se refletem no grau de confiança nas distintas instituiçôes, com a família e a igreja sendo as instituiçôes mais 
confiáveis. No âmbito da esfera pública, a Justiça e as Forças Armadas, identificadas com a manutenção da ordem e caracterizas por um recrutamento teoricamente meritocrático, são as que geram mais confiança.

Do outro lado, são as instituiçôes relacionadas com o sistema democrático as que geram menor confiança - governo, congresso nacional e partidos políticos, inclusive com um decréscimo pela metade no nível de confiança nas últimas décadas. São justamente as instituiçóes que teoricamente têm seus membros escolhidos pela população as que não merecem confiança.

Embora a desconfiança institucional não seja uma característica do conservadorismo - podendo ser interpretada, como no caso de Moisés (2010), como uma avaliação dos resultados deficientes da administração -, as instituições que recebem a confiança da população (família, igreja e militares) reforçam a presença de um componente conservador, em que tradição e hierarquia são elementos importantes.

Tabela 7 - Confiança em Instituições - 1991-2018

\begin{tabular}{l|c|c|c|c|c}
\hline & $\mathbf{1 9 9 1}$ & $\mathbf{1 9 9 7}$ & $\mathbf{2 0 0 6}$ & $\mathbf{2 0 1 4}$ & $\mathbf{2 0 1 8}$ \\
\hline Família & --- & --- & 63,7 & 93,0 & 90,5 \\
\hline Igrejas & 74,9 & 74,5 & 77,8 & 71,1 & 68,8 \\
\hline Forças Armadas & 66,8 & 71,3 & 69,4 & 61,3 & 63,8 \\
\hline Imprensa & 54,4 & 61,3 & 43,5 & 46,1 & 41,1 \\
\hline Justiça & 44,1 & 45,0 & 49,6 & 50,5 & 52,4 \\
\hline Sindicatos & 47,8 & 55,2 & 46,0 & 40,0 & 35,7 \\
\hline Governo & --- & 48,7 & 46,3 & 41,6 & 23,0 \\
\hline Partidos & --- & 32,5 & 21,4 & 16,4 & 13,8 \\
\hline Congresso & 23,3 & 33,7 & 25,1 & 16,4 & 12,8 \\
\hline $\mathrm{N}$ & 1782 & 1143 & 1500 & 1486 & 1762 \\
\hline
\end{tabular}

Fonte: WVS 1991-2018. Respostas confia totalmente ou confia em parte.

A desconfiança institucional, em particular nas organizações mais permeáveis à participação política, ajuda a entender as preferências sobre o modo de governar o país.

De uma forma geral, a existência do sistema democrático parece ser um consenso, com poucas pessoas defendendo uma alternativa abertamente autoritária. Porém, ao se qualificar como seria esse governo, destaca-se uma crença no discurso sobre a superioridade da técnica sobre a política, com mais de $90 \%$ considerando que seria melhor que técnicos tomassem decisóes em vez de políticos.

Também se mantêm próximos de dois terços da população os que defendem um líder forte que não necessite de controles democráticos sobre suas decisões. Uma 
visão de uma democracia com traços autoritários é completada por um percentual de em torno de $40 \%$ que considera positivo ter um governo militar (Tabela 8).

Tabela 8 - Avaliação do modo de governar o país.

\begin{tabular}{l|c|c|c|c}
\hline & 1997 & 2006 & 2014 & 2018 \\
\hline $\begin{array}{l}\text { Ter um líder forte que náo precise se preocupar com } \\
\text { deputados e senadores e com eleiçóes }\end{array}$ & 60,6 & 64,1 & 68,9 & 65,5 \\
\hline $\begin{array}{l}\text { Ter técnicos especializados, ao invés de políticos, } \\
\text { que tomem decisóes que acham que sáo as melhores } \\
\text { para o país }\end{array}$ & 83,1 & 77,8 & 82,7 & 91,0 \\
\hline Ter um governo militar & 45,5 & 35,3 & 35,0 & 44,4 \\
\hline Ter um sistema político democrático & 84,8 & 90,5 & 85,6 & 87,8 \\
\hline $\mathrm{N}$ & 1143 & 1500 & 1486 & 1762 \\
\hline
\end{tabular}

Fonte: WVS 1991-2018. Considera ótimo ou bom.

A definição das características essenciais da democracia pela população indica tratar-se náo de um apoio aberto ao autoritarismo, mas à incorporação, a partir de uma cultura autoritária, da naturalizaçáo de comportamentos autoritários como parte do conceito de democracia, como mostram os dados da Tabela 9.

Tabela 9-É essencial para a democracia

\begin{tabular}{|c|c|c|c|c|}
\hline & & 2006 & 2014 & 2018 \\
\hline \multirow[t]{3}{*}{ O povo escolhe seus líderes em eleiçóes livres } & Média & 8,27 & 8,38 & 8,28 \\
\hline & $\mathrm{N}$ & 1429 & 1387 & 1604 \\
\hline & $s$ & 2,372 & 2,562 & 2,794 \\
\hline \multirow{3}{*}{$\begin{array}{l}\text { As mulheres têm os mesmos direitos que os } \\
\text { homens }\end{array}$} & Média & 8,44 & 8,49 & 8,16 \\
\hline & $\mathrm{N}$ & 1432 & 1428 & 1648 \\
\hline & $s$ & 2,480 & 2,584 & 3,008 \\
\hline \multirow[t]{3}{*}{ O povo recebe seguro-desemprego do governo } & Média & 7,84 & 7,58 & 7,74 \\
\hline & $\mathrm{N}$ & 1419 & 1378 & 1568 \\
\hline & $s$ & 2,514 & 2,910 & 2,996 \\
\hline \multirow{3}{*}{$\begin{array}{l}\text { Direitos do cidadáo protegem a liberdade do povo } \\
\text { contra a opressáo }\end{array}$} & Média & 7,36 & 7,83 & 7,67 \\
\hline & $\mathbf{N}$ & 1388 & 1346 & 1470 \\
\hline & $s$ & 2,681 & 2,721 & 3,036 \\
\hline \multirow{3}{*}{$\begin{array}{l}\text { O Estado faz com que a renda das pessoas seja } \\
\text { igual }\end{array}$} & Média & --- & 5,83 & 5,35 \\
\hline & $\mathrm{N}$ & $-\ldots$ & 1375 & 1524 \\
\hline & $s$ & --.- & 3,386 & 3,630 \\
\hline
\end{tabular}


34 | Rodrigo González, Marcello Baquero e Luis Gustavo Grohmann

\begin{tabular}{l|l|c|c|c}
\hline \multirow{2}{*}{$\begin{array}{l}\text { As forças armadas assumem o governo quando ele } \\
\text { for incompetente }\end{array}$} & Média & 4,92 & 4,99 & 5,09 \\
\cline { 2 - 5 } & $\mathrm{N}$ & 1391 & 1323 & 1500 \\
\cline { 2 - 5 } & $\mathbf{s}$ & 3,332 & 3,505 & 3,732 \\
\hline \multirow{2}{*}{ As pessoas obedecem aos seus governantes } & Média & ---- & 5,25 & 4,89 \\
\cline { 2 - 5 } & $\mathrm{N}$ & ---- & 1383 & 1534 \\
\cline { 2 - 5 } & $\mathbf{s}$ & ---- & 3,321 & 3,382 \\
\hline \multirow{2}{*}{$\begin{array}{l}\text { O governo cobra impostos dos ricos e dá dinheiro } \\
\text { aos pobres. }\end{array}$} & Média & 4,27 & 4,52 & 4,16 \\
\cline { 2 - 5 } & $\mathrm{N}$ & 1401 & 1359 & 1509 \\
\cline { 2 - 5 } & $\mathrm{S}$ & 2,957 & 3,349 & 3,352 \\
\hline Autoridades religiosas interpretam as leis & $\mathbf{N e ́ d i a}$ & 3,78 & 4,02 & 3,45 \\
\cline { 2 - 5 } & $\mathrm{N}$ & 1378 & 1316 & 1460 \\
\cline { 2 - 5 } & $\mathrm{S}$ & 2,674 & 3,127 & 3,006 \\
\hline
\end{tabular}

Fonte: World Values Survey 2006 -2018. 1: não é essencial a 10 é essencial. Média e desvio padrão.

A percepção das características essenciais da democracia segundo a população corrobora as análises de Moisés $(2008)$ e Baquero $(2012,2018)$ sobre a ambivalência e hibridismo. O baixo nível de apoio e satisfação com a democracia, mesmo nos períodos de bonança econômica, indica indiferença ou desapego à democracia como regime (GONZÁLEZ, 2014).

Se há quase um consenso de que são essenciais à democracia eleiçóes livres, igualdade de gênero e proteção de direitos civis, também é incluída a existência do auxílio desemprego, ainda que haja maior divisão sobre a necessidade de taxar os ricos.

A população também se divide em considerar a intervenção militar como um elemento essencial à democracia, que no período recente passou da média 5. A mesma divisão se verifica sobre a necessidade de obedecer às leis, com grande parte da populaçáo aceitando que isso não seja necessário à democracia.

As características do modelo de democracia apoiado pela maioria da população, por um lado, indicam a presença de elementos de conservadorismo - a preferência por formas verticais de tomada de decisóes, como a existência de líderes políticos ou técnicos que não precisam se submeter a instâncias representativas, pode ser relacionada a uma relação de submissão à autoridade. Entretanto, essa posição se contradiz com o apoio relativamente baixo à necessidade de obedecer aos governantes - o que em parte se explica pela característica privatista do convencionalismo, em que família e igreja são as instituições de confiança. O elemento autoritário aparece no apoio à intervenção militar presente em grande parte da sociedade. 
Discutimos a seguir como as características descritas e a trajetória política anterior permitem entender a vitória e o apoio popular ao governo de Jair Bolsonaro como uma continuidade e não como uma ruptura.

\section{Conclusões}

O escritor Sinclair Lewis (2005) escreveu um romance intitulado It can't happen here como um alerta para a possibilidade de uma liderança autoritária de caráter fascista conquistar o governo dos Estados Unidos (e por motivos óbvios o romance voltou a ser popular nos tempos atuais). No caso brasileiro, o título talvez fosse: "Por que não aconteceu antes?"

No caso brasileiro, ainda que o autoritarismo possa ser encontrado em diversas posiçóes do espectro ideológico, o conservadorismo brasileiro tem sido quase exclusivamente autoritário. O liberalismo democrático e conservador, da tradiçáo anglo-saxã, é estranho à nossa prática política, conforme foi exposto na evolução do pensamento político brasileiro. Conservadorismo e autoritarismo são características presentes de forma constante na cultura política brasileira.

Mesmo no período de maior estabilidade econômica, entre 1997 e 2010, e antes que os efeitos da crise dos mercados internacionais de 2008 fosse sentida no Brasil, o apoio à democracia, segundo os dados do Latinobarômetro, foi pouco maior do que $50 \%$, sendo que a satisfaçáo com a democracia náo chegou a $50 \%$, mesmo quando a avaliação positiva do Presidente da República (Lula, em 2010) atingiu os 80\% da população (GONZÁLEZ, 2014).

A realização de eleiçôes contínuas não parece ter tido um efeito de reforço nos valores democráticos (BAQUERO e GONZÁLEZ, 2011). Ainda que o país viva seu período mais longo da história de democracia (ainda que não sem incidentes, como o afastamento de Dilma Rousseff em 2016), sua prática não ampliou o apoio da população ao regime nem eliminou a existência de uma parcela da população que apoia posiçôes autoritárias como a intervenção militar para solucionar problemas políticos.

A transição para a democracia nos anos 80 pode ser entendida não como uma rejeição dos valores do regime autoritário, mas de seu fracasso econômico. A devolução negociada do poder aos civis passou a estes a responsabilidade de tratar da estabilidade monetária e do desemprego, sem tocar diretamente nas violaçóes de direitos, atingidas por uma anistia geral (GONZÁLEZ, 1994).

Manteve-se, por parte da populaçáo, uma avaliação positiva do passado autoritário, inclusive com a existência de uma "nostalgia da ditadura" (CASTRO, 
2014), em que jovens que não viveram o período o avaliam como melhor do que a atualidade, o que permitiu a Bolsonaro, em suas mais de duas décadas como deputado, defender publicamente o legado do período ditatorial.

A pouca afeição ao modelo liberal de democracia não pode ser considerada uma característica exclusiva dos grupos de direita. Seguindo a mesma tradição do sistema partidário do império, quando se dizia que nada era mais conservador que um liberal no poder, em muitos casos os governos considerados progressistas ou de esquerda reproduziram as mesmas práticas que criticavam na direita.

Combina-se, em parte da população, uma visão que pode ser considerada progressista em termos econômicos, de apoio à igualdade social ou à distribuição de renda, com o amplo apoio à participação do Estado na manutenção de políticas sociais, com posiçóes conservadoras nas relaçóes pessoais, com particular influência do pensamento cristão e aceitação de práticas autoritárias.

Uma destas posiçóes é o moralismo radical, que pode ser visto como parte do convencionalismo, com elementos do que Altemeyer chama de double standards, que caracterizam tanto valores do conservadorismo como do autoritarismo.

Indicando que não se trata apenas de um apelo meramente limitado ao período eleitoral, o moralismo fez parte do comportamento de diferentes presidentes eleitos por alianças conservadoras ao longo da história brasileira. O Marechal Dutra baniu os jogos de azar e fechou os cassinos nos anos 40. Jânio Quadros propôs, como presidente, a restrição das corridas de cavalos e do tamanho dos trajes de banho nos concursos de beleza.

O moralismo na política brasileira, no entanto, nunca foi exclusivo dos grupos políticos identificados com a direita. A denúncia de que o Congresso Nacional é um espaço que explora o clientelismo e o patrimonialismo, um dos elementos de enfrentamento entre o Presidente Bolsonaro com os deputados (OYAMA, 2020), também fez parte do discurso de partidos de esquerda nas últimas décadas, contribuindo para a manutenção de baixos níveis de confiança institucional. Ficou célebre, como parte de uma música popular, a frase de Lula em 1993, que afirma "Há no Congresso uma minoria que se preocupa e trabalha pelo país, mas há uma maioria de uns 300 picaretas que defendem apenas seus próprios interesses"3.

O ativismo judicial que alimentou a chamada "Operação Lavajato" e projetou o atual Ministro da Justiça do Governo Bolsonaro, Sérgio Moro, celebrizado por ter proferido a sentença de condenação que levou à prisão de Lula, foi iniciado na década

${ }^{3}$ Canção Luiz Inácio (300 Picaretas) do Grupo Paralamas do Sucesso. 
de 90 com amplo apoio de partidos de esquerda como o PT, como parte de uma agenda de combate à corrupçáo, que era vista como tendo como alvo os integrantes dos partidos mais conservadores.

Da mesma forma, a legislação utilizada para impedir a candidatura de Lula em 2018, a Lei da Ficha Limpa, foi resultado de iniciativa popular, com ampla mobilização na coleta de assinaturas por parte da CNBB e com o apoio dos principais partidos de esquerda para impedir a candidatura de pessoas processadas por corrupção, permitindo não aprovar candidaturas mesmo que o acusado não tivesse uma condenação final.

A exploração política desses padrões de valores e atitudes se relaciona à passagem das campanhas tradicionais, centradas em rádio e televisão, para o uso da internet e redes sociais, o que liberou as mensagens de qualquer verossimilhança ou relação com a realidade.

Nesse sentido, não surpreende a indicação de que parte do eleitorado que teria ajudado a eleger Bolsonaro teria votado em Lula se este tivesse tido sua candidatura validada ${ }^{4}$.

O anticomunismo uniu-se ao conservadorismo de costumes e ao combate à agenda identitária. Porém, dois desses elementos já estão presentes na cultura política brasileira há décadas, com o anticomunismo sendo anterior à Guerra Fria, e o conservadorismo nas relaçóes pessoais tendo elementos que remontam ao império e ao regime escravista.

O elemento novo é a incorporaçáo da agenda identitária, de gênero, étnica e de sexualidade pelos partidos de esquerda no Brasil, uma característica mais próxima do Partido Democrata dos EUA, mas diferente dos partidos socialistas e social-democratas europeus, organizados em torno da clivagem Capital/Trabalho, que em geral foi o modelo dos partidos brasileiros (NORRIS e INGLEHART, 2019; ITUASSU et al., 2019).

Aproveitando o efeito de cultural backlash (NORRIS e INGLEHART, 2019; HUNTER e POWER, 2019), Bolsonaro, que sempre defendeu o autoritarismo e acumulou um histórico de insultos a deputadas mulheres na Câmara de Deputados, incluiu em seu discurso um ataque aos direitos de afrodescendentes e ao público LGBT,

\footnotetext{
${ }^{4}$ Luiz Inácio Lula da Silva apresentou-se como candidato do PT às eleições de 2018, mas teve sua inscrição invalidade pela Corte Eleitoral por ter uma condenação, ainda que não definitiva, de um processo por corrupção oriundo da Operação Lavajato. Foi substituído, um mês antes das eleições, por Fernando Haddad. Nesse momento, as pesquisas eleitorais indicaram um grande crescimento das intenções de voto em Bolsonaro.
} 
com a acusação aos partidos de esquerda de que sua defesa da agenda de identidade é uma ameaça à família tradicional e aos valores cristáos. Sob a influência dos EUA e com a participação de Steve Bannon, incluiu a crítica à ideologia de gênero como una prioridade (MARANHÃO FILHO, COELHO e DIAS, 2018).

O discurso identitário favoreceu a aliança entre o conservadorismo políticoideológico com o religioso, tendo em Bolsonaro a personalidade que combinava essas características e, ainda, com uma aceitação da agenda neoliberal defendida por uma elite econômica.

$\mathrm{O}$ discurso moralista foi capturado pela direita. $\mathrm{O}$ apoio às propostas de Bolsonaro é compatível com os valores dominantes na sociedade brasileira, cuja formação e predomínio foi constante no último século. O repúdio ao politicamente correto já estava presente na sociedade antes da sua candidatura a presidente (DI CARLO e KAMRADT, 2018).

Há uma transformação ocorrendo na sociedade brasileira em termos de afiliação religiosa, o que tem fortalecido valores conservadores; no entanto, essa transformaçáo pode ser vista como uma reaçáo a movimentos de mudança comportamental que tiveram maior sucesso no domínio da agenda de políticas públicas do que na alteração dos valores da população.

Uma vez eleito, o Governo Bolsonaro manteve discursos e ações que seguem apelando a essa identidade conservadora e autoritária. As manifestaçôes incluem não só o Presidente, com ataques dirigidos particularmente à imprensa, como também seus ministros. A Ministra da Família, em uma reunião, comemorou o fato de que, a partir do novo governo, se retornaria à definição de que meninos usam azul e meninas usam rosa, além de propor a abstinência sexual como contraceptivo para os jovens. $\mathrm{O}$ Ministro da Educação denunciou a existência do "marxismo cultural" e da "doutrinação" nas Universidades. O Ministro das Relaçôes Exteriores usou frequentemente linguagem anticomunista. E parte desse espaço foi ocupado por filhos do Presidente, que são parlamentares, em postagens em redes sociais (OYAMA, 2020).

As escolhas de Bolsonaro, em termos de formação de seu Gabinete Ministerial, podem ser consideradas inconsistentes com a estabilidade democrática, mas são totalmente congruentes com as posições de uma parcela importante da população, que compartilha valores conservadores e atitudes que apoiam a presença das Forças Armadas no governo.

Os principais postos de apoio do atual governo federal do Brasil são ocupados por militares, pois, além do Presidente Jair Bolsonaro, que é ex-capitão do exército, e do Vice-Presidente, General Hamilton Mourão, em 2020 os militares com gabinetes 
dentro do Palácio de Governo incluíam o General Augusto Heleno Pereira, no Gabinete de Segurança Institucional; o General Luis Eduardo Ramos, na Secretaria de Governo; o Major da Policia Militar Jorge Oliveira, na Secretaria Geral da Presidência e, depois de fevereiro de 2020, o General Walter Souza Braga Netto na Casa Civil, quando substituiu o último ministro civil, Onix Lorenzoni nos postos palacianos. Também são militares de carreira os ministros da Defesa, de Ciência e Tecnologia (um ex-astronauta), de Infraestrutura e, despois do início da pandemia de Covid-19, o da Saúde. Também diversas outras estruturas do governo são ocupadas por ex-militares.

A inclusão de militares nos principais cargos de apoio da Presidência da República tem um efeito completamente diferente nos EUA em relação ao Brasil. Embora possa ser compartilhado o fato de que são apresentados como tecnocratas competentes, nos EUA não se permitem militares na ativa, nem há apoio à intervenção das Forças Armadas na política.

Perguntado se isto seria um problema, o Vice-Presidente se manifestou:

\footnotetext{
"Essa é uma preocupação que a gente tem desde o começo do nosso governo. A gente tem que deixar claro que as Forças Armadas continuam do lado de fora, apesar de nós termos a presença de elementos do meio militar. Mas as Forças Armadas estão fora na mão dos seus comandantes. $\mathrm{E}$ isso a gente tem que deixar muito claro o tempo todo porque eventuais erros e acertos do nosso governo náo pode ser debitados na conta delas", disse o vice-presidente (GOMES, 2020).
}

Ao tentar tranquilizar o público e jornalistas, deixando clara a existência de uma separação entre Governo e Forças Armadas, o vice-presidente não parece consciente de que sua afirmação pressupóe que as Forças Armadas não só não compóem o governo, como não estáo subordinadas a ele, mas a seus comandantes, e não ao poder civil.

Porém, essas posiçôes são congruentes com os valores e atitudes da população. As Forças Armadas são a instituição pública que goza dos maiores níveis de confiança, e, para grande parte da população, sua intervenção na política não só não é indesejável como é parte da democracia.

Assim, não se pode falar de uma desconsolidação da democracia nos termos que propõem Foa e Mounk (2017), já que, segundo os critérios de Linz e Stepan (1996), ela nunca esteve consolidada, nem de uma mudança radical de modelo político, com a eleição de um candidato de extrema-direita. 
O comportamento racista e misógino do Presidente e muitas de suas propostas, contra direitos das mulheres, dos afrodescendentes e do público LGBT, assim como a defesa da intervenção dos militares na política, não só encontra apoio nos valores e atitudes da população, mas tem raízes em uma tradição antiga.

Os dados apresentados não indicam que ocorra uma transição do regime democrático para o autoritarismo no curto prazo. Porém, esta é uma possibilidade que não pode ser descartada e, se vier a ocorrer, tanto náo poderá ser considerada uma surpresa como provavelmente contará com o apoio de uma ampla parcela da sociedade.

Rodrigo Stumpf González é Professor do Programa de PósGraduação em Ciência Política da Universidade Federal do Rio Grande do Sul. E-mail: rodrigo.stumpf@ufrgs.br.

Marcello Baquero é Professor do Programa de Pós-Graduação em Ciência Politica da Universidade Federal do Rio Grande do Sul. Email: nupesal@ufrgs.br.

Luis Gustavo Mello Grohmann é Professor do Programa de PósGraduação em Ciência Politica da Universidade Federal do Rio Grande do Sul. E-mail: lgmgrohmann@gmail.com.

\section{Referências}

ADORNO, Theodor W. et al. The authoritarian personality. New York: Harper and Row, 1950.

ALBRIGHT Madeleine. Fascism: A Warning. [S.1.]: William Collins, 2018.

ALMOND, Gabriel. The civic culture: Prehistory, retrospect, and prospect. Irvine: Center for the Study of Democracy, 1996. (Research Paper Series in Empirical Democratic Theory, no. 1).

ALMOND, Gabriel; VERBA, Sidney. The civic culture: Political attitudes and democracy in five nations. Princeton, NJ: Princeton University Press, 1963.

ALTEMEYER, Robert. The Authoritarians. 2006. Disponível em: <http://www. theauthoritarians.com>. Acesso em: 06 fev. 2021.

ALTEMEYER, Robert. Right-wing authoritarianism. [S.1]: University of Manitoba Press, 1981.

BAPTISTA, Saulo de Tarso C. Cultura política brasileira, práticas pentecostais e neopentecostais: a presença da Assembléia de Deus e da Igreja Universal do Reino de Deus no Congresso Nacional (19992006). 2007. 563 f. Tese (Doutorado em Ciências da Religião) - Programa de Pós-Graduação em Ciências da Religião, Universidade Metodista de São Paulo, São Bernardo do Campo, 2007. 
BAQUERO, Marcello. Democracia Inercial: Assimetrias entre Economia e Cultura Política na América Latina. Porto Alegre: UFRGS, 2018.

BAQUERO, Marcello. Memória política e constituição da cultura política brasileira. Ciências Sociais Unisinos, v. 48, n. 2, p. 84-92, 2012.

BAQUERO, Marcello. Cultura política participativa e desconsolidação democrática: reflexōes sobre o Brasil contemporâneo. Sáo Paulo em perspectiva, v. 15, n. 4, p. 98-104, 2001.

BAQUERO, Marcello; GONZÁLEZ, Rodrigo Stumpf. Cultura política, mudanças econômicas e democracia inercial. Uma análise pós-eleiçôes de 2014. Opiniáo Pública, v. 22, n. 3, p. 492-523, 2016. BAQUERO, Marcello; GONZÁLEZ, Rodrigo Stumpf. Eleiçōes, estabilidade democrática e socialização política no Brasil: análise longitudinal da persistência de valores nas eleiçóes presidenciais de 2002 a 2010. Opinião pública, v. 17, n. 2, p. 369-399, 2011.

BEACH, Derek; PEDERESEN, Rasmus B. Causal case study methods: Foundations and guidelines for comparing, matching, and tracing. Ann Arbor, MI: University of Michigan Press, 2016.

BOBBIO, Norberto. Direita e Esquerda razóes e significados de uma distinçâo política. São Paulo: Unesp, 2001.

CAMPOS, Leonildo S. Os Mapas, Atores e Números da Diversidade Religiosa Cristá Brasileira: Católicos e Evangélicos entre 1940 e 2007. Revista de Estudos da religião, v. 8, n. 4, p. 9-47, 2008.

CARVALHO, José Murilo de. Cidadania no Brasil: o longo caminho. Rio de Janeiro: Civilização Brasileira, 2008.

CARVALHO, José Murilo de. As duas cabeças de Oliveira Viana. In: AXT, Gunter; SCHÜLER, Fernando (Coords.). Intérpretes do Brasil. Cultura e Identidade. Porto Alegre: Artes e Ofícios, 2004.

CASTRO, Henrique Carlos de Oliveira de. Cultura política comparada: democracia e mudanças econômicas: Brasil, Argentina e Chile. Brasilia, Verbena, 2014.

COUTO E SILVA, Golbery D. Geopolítica do Brasil. Rio de Janeiro: J. Olympio, 1967.

CRIPPA, Adolpho (Coord). As idéias políticas no Brasil. São Paulo: Convívio, 1979.

DI CARLO, Josnei; KAMRADT, João. Bolsonaro e a cultura do politicamente incorreto na política brasileira. Teoria e Cultura, v. 13, n. 2, p. 55-72, 2018.

EASTON, David. A framework for political analysis. Englewood Cliffs, NJ: Prentice-Hall, 1965.

FAORO, Raymundo. Os donos do poder. Formaçáo do patronato político brasileiro. Porto Alegre: Globo, 1973.

FAUSTO, Boris et al. História Geral da Civilizaçáo Brasileira. Rio de Janeiro Bertrand, 2007. Tomo III - O Brasil Republicano.

FERNANDES, Ananda S. A reformulação da Doutrina de Segurança Nacional pela Escola Superior de Guerra no Brasil: a geopolítica de Golbery do Couto e Silva. Antíteses, v. 2, n. 4, p. 831-856, 2009.

FERNÁNDEZ-PRADOS, Juan Sebastián; CUENCA-PIQUERAS, Cristina; GONZÁLEZMORENO, María José. International public opinion surveys and public policy in Southern European democracies. Journal of International and Comparative Social Policy, v. 35, n. 2, p. 227-237, 2019.

FLEISCHER, David et al. Da distensão à abertura: as eleiçóes de 1982. Brasília: Editora Universidade de Brasília, 1988.

FOA, Roberto Stefan; MOUNK, Yascha. The signs of deconsolidation. Journal of Democracy, v. 28, n. 1, p. 5-15, 2017.

FREYRE, Gilberto. Casa-grande \& senzala. Rio de Janeiro : Global Editora e Distribuidora Ltda, 2019. 
GEORGE, Alexander L.; BENNETT, Andrew. Case studies and theory development in the social sciences. Cambridge: MIT Press, 2005.

GOMES, Pedro Henrique. Eventuais erros do governo 'não podem ser debitados' na conta das Forças Armadas', diz Mourão. G1, 14 fev. 2020. Disponível em: <https://g1.globo.com/politica/noticia/2020/02/14/mourao-diz-que-eventuais-erros-e-acertos-dogoverno-nao-podem-ser-debitados-na-conta-das-forcas-armadas.ghtml>. Acesso em: 14 fev. 2020. GONZÁLEZ, Rodrigo Stumpf. Qualidade da democracia, eleiçôes presidenciais e apoio à democracia na América Latina. Temas y Debates, n. 28, p. 13-28, 2014.

GONZÁLEZ, Rodrigo Stumpf. Direitos humanos e democracia na transição brasileira: OAB, CNBB e Anistia Internacional. Porto Alegre: UFRGS, 1994.

HIRSCHMAN, Albert Otto. A retórica da intransigência: perversidade, futilidade, ameaça. São Paulo: Companhia das letras, 1992.

HOLANDA, Sérgio Buarque de. Raízes do Brasil. São Paulo: Companhia das Letras, 1995.

HOLANDA, Sérgio Buarque de et al. História geral da civilização brasileira. São Paulo: Difusão Europeia do Livro, 1960a. Tomo I - A época colonial.

HOLANDA, Sérgio Buarque de et al. História geral da civilização brasileira. São Paulo: Difusão Europeia do Livro, 1960b. Tomo II - O Brasil monárquico.

HUNTER, Wendy; POWER, Timothy J. Bolsonaro and Brazil's illiberal backlash. Journal of Democracy, v. 30, n. 1, p. 68-82, 2019.

HUNTINGTON, Samuel P. Conservatism as an Ideology. American political science review, v. 51, $\mathrm{n}$. 2, p. 454-473, 1957.

IANNI, Octávio. Pensamento social no Brasil. Bauru: Edusc, 2004.

INGLEHART, Ronald; WELZEL, Christian. Modernization, cultural change, and democracy: The human development sequence. Cambridge: Cambridge University Press, 2005.

ITUASSU, Arthur et al. Comunicación política, elecciones y democracia: las campañas de Donald Trump y Jair Bolsonaro. Perspectivas de la comunicación, v. 12, n. 2, p. 11-37, 2019.

JORSTAD, Erling. The new Christian Right, 1981-1988: prospects for the post-Reagan decade. New York : Edwin Mellen Press, 1987.

LAMOUNIER, Bolívar; CARDOSO, Fernando Henrique (Eds.). Os partidos e as eleiçóes no Brasil. Rio de Janeiro: Paz e Terra, 1975.

LEAL, Victor Nunes. Coronelismo, enxada e voto: o município e o regime representativo no Brasil. Local: Companhia das Letras, 2012.

LEVITSKY, Steven; ZIBLATT, Daniel. Como as democracias morrem. Rio de Janeiro: Zahar, 2018. LEWIS, Sinclair. It Can't Happen Here. 1935. New York: New American Library, 2005.

LINZ, Juan José. Totalitarian and authoritarian regimes. Boulder: Lynne Rienner Publishers, 2000. LINZ, Juan J.; STEPAN, Alfred. Problems of democratic transition and consolidation: Southern Europe, South America, and post-communist Europe. Baltimore John Hopkins University Press: JHU Press, 1996.

MACHADO, Maria C.; BURITY, Joanildo. A Ascensão Política dos Pentecostais no Brasil na Avaliação de Líderes Religiosos. Dados, v. 57, n. 3, p. 601-631, 2014.

MANNHEIM, Karl. Conservatism: A Contribution to the Sociology of Knowledge. London: Routledge, 1986. 
MARANHÃO FILHO, Eduardo Meinberg; COELHO, Fernanda Marina F; DIAS, Tainah B. Fake news acima de tudo, fake news acima de todos: Bolsonaro e o 'kit gay', 'ideologia de gênero' e fim da 'família tradicional'. Correlatio, v. 17, n. 2, p. 65-90, 2018.

MARSHALL, Thomas Humphrey. Cidadania, classe social e status. Rio de Janeiro: Zahar, 1967.

MATTA, Roberto da. Carnavais, malandros e heróis: para uma sociologia do dilema brasileiro. Rio de Janeiro: Rocco, 1979.

MENEGUELLO, Raquel. PT: Inovação no sistema partidário brasileiro. Campinas: Unicamp, 1987.

MERCADANTE, Paulo. A consciência conservadora no Brasil: contribuição ao estudo da formação brasileira. Rio de Janeiro: Civilização Brasileira, 1965.

MOISÉS, José Alvaro (Org.). Democracia e Confiança: Por que os Cidadáos Desconfiam das Instituiçóes Democráticas? São Paulo: Editora da Universidade de São Paulo, 2010.

MOISÉS, José Álvaro. Cultura política, instituiçôes e democracia: liçôes da experiência brasileira. Revista brasileira de ciências sociais, v. 23, n. 66, p. 11-43, 2008.

MOISÉS, José Álvaro. Os Brasileiros e a democracia. São Paulo: Ática, 1995.

NORRIS, Pippa. The globalization of comparative public opinion research. In: ROBINSON, Neil; LANDMAN, Todd (Eds.). Handbook of comparative politics. London: Sage, 2009. p. 522-540.

NORRIS, Pippa (Ed.). Critical citizens: Global support for democratic government. Oxford: OUP Oxford, 1999.

NORRIS, Pippa; INGLEHART, Ronald. Cultural backlash: Trump, Brexit, and authoritarian populism. Cambridge: Cambridge University Press, 2019.

OYAMA, Thaís. Tormenta: O governo Bolsonaro: crises, intrigas e segredos. São Paulo: Companhia das Letras, 2020.

POERNER, Arthur. O poder jovem. Rio de Janeiro: Civilização Brasileira, 1968.

PRANDI, Reginaldo; SANTOS, Renan William dos. Quem tem medo da bancada evangélica? Posiçóes sobre moralidade e política no eleitorado brasileiro, no Congresso Nacional e na Frente Parlamentar Evangélica. Tempo social, v. 29, n. 2, p. 187-214, maio 2017.

RAY, John J. Does Authoritarianism of Personality go with conservatism? Australian Journal of Psychology, v. 31, n. 1, p. 9-14, 1979.

RAY, John J. Conservatism, authoritarianism, and related variables: A review and empirical study. In: WILSON, Glenn (Org). The psychology of conservatism. London: Academic Press, 1973. p. 17-35.

REIS, Fábio Wanderley et al. Os partidos e o regime: a lógica do processo eleitoral brasileiro. São Paulo: Símbolo, 1978.

ROBIN, Corey. The reactionary mind: conservatism from Edmund Burke to Donald Trump. Oxford: Oxford University Press, 2017.

RODEGHERO, Carla Simone. Religião e patriotismo: o anticomunismo católico nos Estados Unidos e no Brasil nos anos da Guerra Fria. Revista Brasileira de história, v. 22, n. 44, p. 463-488, 2002.

SANTOS, Wanderley Guilherme dos. Cidadania e justiça: a política social na ordem brasileira. Rio de Janeiro: Editora Campus, 1979.

SCHWARTZMAN, Simon. Bases do autoritarismo brasileiro. Brasília: Ed. UnB, 1982.

SCRUTON, Roger. The meaning of conservatism. Harmondsworth: Penguin Books, 1980.

SILVA, Fábio Mariano E.; CUNHA, Eleonora Schettini M. Process-tracing e a produção de inferência causal. Revista Teoria \& Sociedade, v. 22, n. 2, 2014. 
44 | Rodrigo González, Marcello Baquero e Luis Gustavo Grohmann

SOUZA, Maria do Carmo Campello. Estado e partidos políticos no Brasil (1930 a 1964). São Paulo: Alfa-Omega, 1976.

TRINDADE, Hélgio. Base da democracia Brasileira: Lógica Liberal e prática autoritária. In: ROUQUIÉ, Alain et al. Como renascem as democracias. São Paulo: Brasiliense, 1985.

WILSON, Glenn D.; PATTERSON, John R. A new measure of conservatism. British Journal of Social and Clinical Psychology, v. 7, n. 4, p. 264-269, 1968.

WORMALD, Benjamin. Religião na América Latina: Mudança Generalizada em uma Região Historicamente Católica. Pew Research Center, 13 nov. 2014. Disponível em: <http://www.pewforum.org/files/2014/11/PEW-RESEARCH-CENTER-Religion-in-LatinAmerica-Portuguese-Overview-for-publication-11-13.pdf>. Acesso em: 11 maio. 2019.

Texto recebido em 19 de janeiro de 2021. Aprovado em 03 de fevereiro de 2021. 